\title{
LOVE THE ONE YOU'RE WITH: WOMAN AT THE CROSSROADS OF TRUE LOVE AND REAL LIFE
}

\author{
Tatik Muflihah \\ Nahdlatul Ulama University of Surabaya \\ e-mail:miraicha@unusa.ac.id
}

\begin{abstract}
Conflict is a situation frequently occurs in people's lives. The source of conflict is usually originated from a personal and interpersonal misunderstanding in a relationship and poor communication. As a part of human's creativity, literary work sometimes reflects people problematic life. One of those is internal and external conflict faced by the main character of the novel Love the One You're With by Emily Giffin. This paper aims at investigating the conflicts faced by the main character of the novel and the strategy used to resolve those. The result of the study shows that the main character of the novel faced both internal and external conflicts. The internal is the conflict of Ellen and her own mind when she run into her true love and her real life as a wife. It becomes a conflict as she trapped and started to hesitate her own self whether go along with her emotional love or go back to her husband. The external conflicts occur between Ellen and all the characters of the novel. Thus, the main character of the novel had a complicated struggle to save her marriage live.
\end{abstract}

\section{INTRODUCTION}

Novel is one of literary work which tries to reveals features of human life. The author usually describes human life either in existence as individual or relating with another. The language of novel is without meter or regular rhythm. This means that it is in the form of common writing as we can meet in article of nonfiction. Further, the language is easy to be understood comparing to another form of literary work such as: the poem.

Many people believe that literature comes from the author's imagination and it is just words form sentences on a piece of paper. This can be said that the story of a novel is a reflection of the authors experience or they take from environment. Reader (1987:6) explains that "Fictitious prose narrative of volume length portraying characters and actions representative of real life in continuous plot". Meanings that a novel is a kind of fiction; a represen- tation of a story or story defining figure and event action.

A novel is generally elaborated by two elements; intrinsic and extrinsic elements. The function of intrinsic element is to build up the literary imagination itself such as theme, plot, setting, character, conflict, point of view, and etcetera. A conflict is the dramatic struggle between opposing forces in a story. A conflict refers to the different drives of the characters or forces involved in the story. This may be in the form of internal or external - that is, it may occur within a character's mind or between a character and exterior forces, (or point(s) of view). A conflict leads tension and interest in a story by adding doubt as to the outcome.

Kenney (1966:19) explains there are many kinds of conflicts such as: a conflict within a single man or internal, external such as: a conflict between man and society, between man and nature, and so on. Then, conflict denotes to a character which dealt with situation in the 
story. This paper is aimed to analyze the main character's conflict in Love the One You're With.

Love the One You're With is a novel about Ellen Dempsey - a married woman who begins to question herself whether the life she is living is the one she is meant to live. She runs into her ex-boyfriend Leo for the first time in eight years. Although he brought out the worst in her and left her heartbroken with no explanation, he is also the love she could never quite forget.

The focus of the study is to describe how the main character faces her conflict; her conflict within herself, her conflict with another individual and also her conflict with society. It is conflict that makes a story full with intense. How it is started, faced, and solve it for better solution in order to get wisdom living. Conflict includes in intrinsic element of the novel. The writer tries to analyze the conflicts of the novel since she found many problems faced by the main characters of the novel. She tries to explore strategies of managing and possibly resolving conflicts by the main character of the novel both internal and external. Thus the focus of the study is not only analysis on internal conflict but also the social conflict. Social conflict is conflict between the characters against another characters (Kenny, 1966:32). The main character has conflict in her social life. The conflict happens when the actor has problem with other. It is the struggle between opposing forces in the story.

\section{LITERATURE REVIEW}

Conflict is a struggle between opposing forces. There are two kinds of conflict in the stories. The external conflict is a struggle that takes place in character and an outside force.
Character may face several types of outside forces. The outside forces can be in the form of; other characters, community or the nature. While, the internal conflict is a struggle of pace inside a characters mind.

A Character is the description of a real person that showing in the story (Jones in Nurgiyantoro 1994:165). Character is a representation of human being, the inner itself that determines thought, speech and behavior. Characters in fiction can be classified as major and minor, static and dynamic (Diyanni, 2001:55). This novel involves several characters. These are categorized into two different types; main characters and supporting characters.

\section{METHOD}

The method used in this study is qualitative method. Theory of literature is used to analyze to the problem then the writer uses psychological approaches. The psychological approach is used to describe human attitude or behavior. In analyzing conflict in love the one you're with, the writer focuses on conflict faced by the main the character, both internal and external.

\section{Technique of Collecting the Data}

There are some steps in collecting the data, such as: reading the novel and find out the conflicts of the main character in the novel love the one you're with.

\section{Technique for analyzing the Data}

The data of this research is analyzed qualitatively. The process of analysis of the data through some step as follows: Firstly, identified the conflicts in the novel. Secondly, classified the conflict by using analysis data card to classify the external and internal conflict. The last step 
writer makes the interpretation in this case estimates or gives a critic on the consequence of the conflict itself toward the character and society where she lives.

\section{RESEARCH FINDING AND DISCUSSION}

After collecting the data, the writer presents the finding and discussion of the study at once. The source of the data is a novel entitled love the one you're with by Emily Giffin. The major character found in this novel is Ellen and the other minor characters such as Andy, Leo, Margot, Suzan, etc. The data to be analyzed is the conflict faced by the main character both internal and external. Further, it is also found that there are two different types of conflicts; internal and external. The description can be seen in the next part.

\section{Internal Conflict}

The conflict between Ellen and her own mind as she had relationship with Leo (Her Exboyfriend) while she has been married by Andy.

\section{a) The source of Conflict}

Ellen has relationship with her ex-boyfriends after breaking up for eight years. She realized that it is forbidden love. Then, she chose to hidden the relationship from her husband, her family and friend though she felt guilty to her marriage.

This can be seen in the following sentence:

"... And one of them was Leo. The one I would love before I loved Andy. The one I would grow to hate, but still love, long after we broke up. The one I would finally, finally get over. Then see again, years later, in a New York City crosswalk.”(P.13-14, L: 34, 1-4).

From the above sentence, it can be seen that Leo was Ellen's never ending love. After breaking up for at least eight years, Leo appeared and offered his love to Ellen. Although he had ever made Ellen heartbroken but he was still the one. She struggled to ignore him by having her new love, Andy. She wanted to stop thinking of him, but she failed. In fact, Ellen loved him indeed. This shows that Ellen had conflict within her own mind. She was at crossroad her true love and her real love; Love and Andy.

\section{b) The Strategy of Conflict Management}

Ellen kept the relationship with Leo secretly from her husband. She kept in touch with Leo either by phone or email. When there is a photography project, she never communicates to Andy that she was working with Leo. She felt guilty and uncomfortable, but her love to Leo makes Ellen took the risk. Ellen problematic love story can be seen in the following sentence:

"To share my feelings with a friend would constitute an act of disloyalty to my husband. To tell my older and very cynical sister, Suzanne, might unleash a storm of caustic remarks about marriage and monogamy. To write of it in my journal would elevate its importance, something I was determined not to do. And to tell Andy would be some combination of stupid, self-destructive, and hurtful. I was bothered by the lie of omission, a black mark on our fledging marriage, but decided it was for the best." (P. 2, L: 24-33)

This statement expresses internal conflict faced by Ellen. She felt completely wrong and no way out. She realized that having relationship with Leo is absolutely immoral, but Ellen could not deny her love to him. Finally, she kept the tricky problem and not to tell anyone. This also shows that Ellen is a woman who has high dignity. She preferred not to tell her dilemma to anyone; friends, family and even Andy or write it on her journal. She chose to resolve her 
problem by concealing it. As she thought it was the best thing she could do.

\section{External Conflict}

\section{1) Conflict between Ellen and Leo}

\section{(a) The source of Conflict}

Ellen wanted to have more serious relationship with Leo. But he is anti-commitment man. This made Ellen frustrated then decided end the relationship. Furthermore, Leo agreed to Ellen and this made her more painful.

This can be seen in the following fragment:

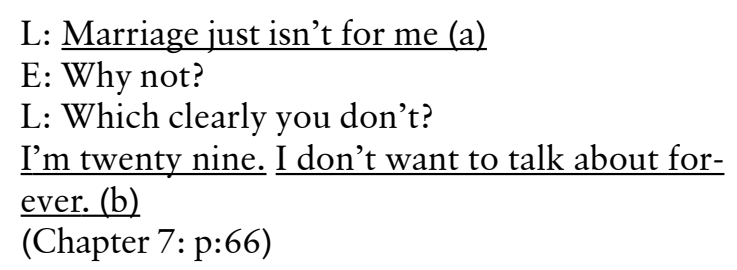

The underlined sentences indicates external conflict between Ellen and Leo. He considered that he was still too young to get marriage. Leo did not want to have more serious relationship with Ellen. In addition, he did not want to have discussion about marriage anymore. Shortly, he just wanted to have enjoyable relationship without any obligation. This highlights Leo's personal character as anti-commitment man.

\section{(b) Strategy to Manage Conflict}

After trying to communicate to Leo about marriage and he rejected it. He asked Ellen to forget the discussion about marriage. Ellen agreed and tried to calm herself. This can be seen in the following fragment:

"I nodded, pretending to be placated (a), a few minutes later we made love and I convinced myself that everything would be fine (b). We were just going through a rough patch, a few growing pains, and I need to be patient, ride the wave, take the bad thing (c)..." (Chapter 7: p: 66)
From the underlined sentences we know that Ellen tried to calm herself. She agreed to Leos' request not to discuss on wedding plan anymore. She tried to convince herself that everything would be fine. She considered that one thing she needs to do is to be more patience and continue the relationship. Ellen's effort can be considered as a form of the way how to manage the conflict between characters: Leo vs Ellen. Briefly, Ellen tried to ignore all the fact about Leo and she is ready to face the consequence of her choice.

\section{2) Conflict between Ellen and Andy}

\section{(a) Source of Conflict}

Ellen told Andy about her work with Leo. As a husband he was curious why it should be with her ex-boyfriend. He felt that Ellen had a big deal with her ex-boyfriend. The situation seems to be more complicated as and Andy leave Ellen alone in the night. The description can be seen in the following fragment:
A: then why didn't you tell me?
E: I don't want to upset you.
A: Well, not telling me makes it big deal.
E: I know. I'm sorry...But I really want the work...this kind of work. I really miss it. I really miss New York.
A: So go work there.
E: That's what I'm doing
A: But why does it have to be with Leo?
(Chapter 30: 296-301)

The underlined sentences show external conflict between characters namely: Ellen and Andy. They argued and defended their individual ego. Andy was very angry with Ellen since she never talk about her work with Leo earlier. However, Ellen claimed that she did it just she didn't want to make Andy upset. By the end of their dispute, Andy left home in the night. This can be said that the conflict is in the 
form of Andy's great jealousy to Ellen and his sense of possession to his wife.

\section{(b) Strategy of Conflict Management}

Having fiercely argumentation, Andy left Ellen at home in the night. This indicates unresolved conflict. Ellen tried to hold back Andy in order to stay at home and asked for another chance to have discussion. The following fragment describe the situation:

E: Where are you going?

A: Out, I'm certainly not gonna sleep here tonight and kiss you good-bye in the morning like some kind of stupid chump.

E: Andy ... please try to understand. It's not you... It's me... I just... need to do this. Please. Can't we talk about it more? (Chapter 30: 301)

These underlined sentences indicates Ellen's effort to manage the conflict by asking Andy not to go out and left her in the night. Also, she tried to negotiate Andy to have another discussion on this.

\section{3) Conflict between Ellen and Margot}

\section{(a) Source of Conflict}

Margot is Ellen's best friend and also her sister in law. She disliked Ellen's relationship with Leo. Margot's considered that Ellen becomes dependent girl. She was questioning to Ellen whether Ellen loved to or just lust. This can be seen in next fragment: (1)

M: I don't know what you're so mopey about. You were never really in love with him. You were only in lust. The two are often confused.

E : It was love. I still love him. I will always love him.

M: No, You were only in love with the idea of love...

E : You are wrong
M: Haven't you ever heard that true love is supposed to make you a better person? Uplift you.

E : I was better a better person with Leo. He did uplift me.

M: Actually you sucked when you were with Leo...He made you needy...spineless, insecure, and one-dimensional. It was like I didn't even know you anymore. You weren't the same person with him. I think the whole relationship was... unhealthy.

E : You were just jealous (Chapter 7: 71-72).

All the sentences above describe external conflict between Margot and Ellen. They arguing about Ellen relationship with Leo. Margot thought Ellen never love Leo instead only lust him. Margot believed that if Ellen loves Leo, she would be better person. In fact she found that Ellen to be different girl, dependent, spiritless, and unconfident. Nevertheless, Ellen rejected all Margot consideration.

\section{(a) Strategy of Conflict Management}

After breaking up from Leo, it seems to Margot that Ellen to be a different character. She was depressed, hopeless, and pathetic. Margot tried to help Ellen rise from her problem. She challenged her to provide her best creation on photography. Thus, she suggested Ellen to join a part time on her hobby.

E : He did too make me better.

M: Well, if that's true, Ellen then show me one good photo you took when show me one good photo you look when you were with him. Show me he inspired you. Prove me wrong. (Chapter:....)

The underlined sentence shows that Margot tried to manage the conflict with Ellen. She convinced Ellen that Leo was not a good man for her. Instead he just brought an evil thing for Ellen. Therefore she asked Ellen to prove that Leo was able to give positive impact to her. 


\section{4) Conflict between Ellen and Suzanne}

\section{(a) Source of Conflict}

Suzanne is Ellen's elder sister. In the beginning, Suzanne did not mind when Ellen talked about her relationship again with Leo. She thought it was common thing. However, she warned Ellen to end the relationship as she observed it would be harmful to her marriage. This can be seen in the next description:

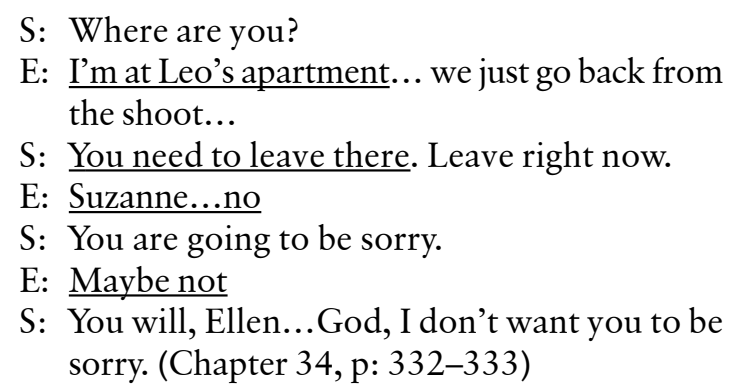

S: You need to leave there. Leave right now.

E: Suzanne...no

S: You are going to be sorry.

E: Maybe not

S: You will, Ellen...God, I don't want you to be sorry. (Chapter 34, p: 332-333)

The underlined sentences indicated external conflict between Suzanne and Ellen. Suzanne asked Ellen to stop the relationship since she didn't want Ellen would be regret. Suzanne thought that Ellen had already made the situation worse, it would be harmful for Ellen marriage. However, Ellen ignored it. She tried to ensure Suzanne, that everything would be fine.

\section{(b) Strategy to manage the conflict}

After having argumentation with Suzanne, Ellen tried to manage the conflict with her sister. This can be seen in the next description:

S: I'm not saying that Andy's perfect. Far from it...But

E: But what?

S: But they're your family. And you are lucky to have... a family

E: You're my family too.

S: I know. You're mine. But C'mon Ell. You know what I mean... They're the real Norman Rockwell family. And they include you in everything. They count you as one of their own. You're one of them. (Chapter 34, P: 334)
In this part of conversation, Suzanne tried to manage the conflict by saying that Ellen was the lucky woman as she was becoming a family member of Andy. Andy's family always incorporated Ellen in the whole event of the family. Suzanne highlighted though Andy was not a perfect husband, but his family put her as the real family member. Briefly, Suzanne reminded Ellen nothing is more important rather than a family.

\section{The Value of Conflict in Love the one you're with}

\section{Value of Internal Conflict}

The value of the internal conflict can be found in the novel that a good communication has significant point in marriage. A conflict faced by Ellen - the main character of the novel is as the result of her lack of communication with her husband Andy. Ellen did not tell Andy about a meeting with her ex-boyfriend - Leo. A good communication in marriage will overcome any kinds of problems. In addition, sometimes love drives away someone's logic. This means that when someone falling in love it is hard to have objective resolution.

\section{Value of External Conflict}

The value of external conflict in the novel that no one can live alone in the world. This means that each of individual always required the help from others to remind, support, and provide advice. Therefore, all of human being would never be able to ignore the role others friends and family. In this novel the main character faced many external conflicts. These also known as character versus other characters also known as man vs. man, such as: Ellen vs. Andy, Ellen vs. Leo, Ellen vs Margot and Ellen 
vs. Suzanne. Mostly, all the characters had opposing idea with the main character- Ellen in behaving her problem.

\section{Conclusion}

Based on the research findings, it can be concluded as follows:

Conflicts of the main character:

The main character of Love the one you're with novel is Ellen, she faced both internal and external conflict. Internal conflict is conflict within Ellen and her own mind. This kind of conflict arises when she kept a forbidden relationship with her ex-boyfriend. While, external conflict is conflict faced by the main character versus other characters. In this Love the one you're with, there are several characters who had conflict with Ellen. They are: Leo (Ellen's ex-boyfriend), Andy (Ellen's husband), Margot (Ellen's friend and her sister in law), and Suzanne (Ellen's sister). Furthermore, the main character had her own way to resolve the conflicts. Ellen decided not to tell her internal problem to others, rather kept it by her own self. In addition, in resolving the external conflict Ellen still being in trapped by a sense of love for Leo. She's trying to convince people around her that she was able to maintain the relationship. This also gives an idea that woman always concerns on her the feelings rather than logic and reality.
Values that reflected from the conflict:

The value of internal conflict is communication in marriage life is very significant thing. Trying to be an open minded human is useful in some cases. Not following the feeling.

The value of external conflict is when you did immoral thing all of man around you will argue. They show their attention and love.

\section{References}

Diyanni, Robert. 2001. Literature Reading, Fiction, Poetry, and Drama. McGraw-Hill International Edition.

Giffin, Emily. 2008. Love the One You're With. New York: St. Martin's Press.

Jones, Edward H, Jr. 1968. Outlines of Literature (Short Stories, Novels and Poems). New York: El Comino College.

Kenney, William. 1966. How to Analyze Fiction (A Critical Guide to Appreciation of Short Stories, Novellas and Novels). New York: Monarch Press.

Nurgiyantoro, Burhan. 2012. Teori Pengkajian Sastra. Yogyakarta: Gadjah Mada University press.

http://www.teenink.com/opinion/all/article/ 221593/The-Reflection-Of-Literature/ 